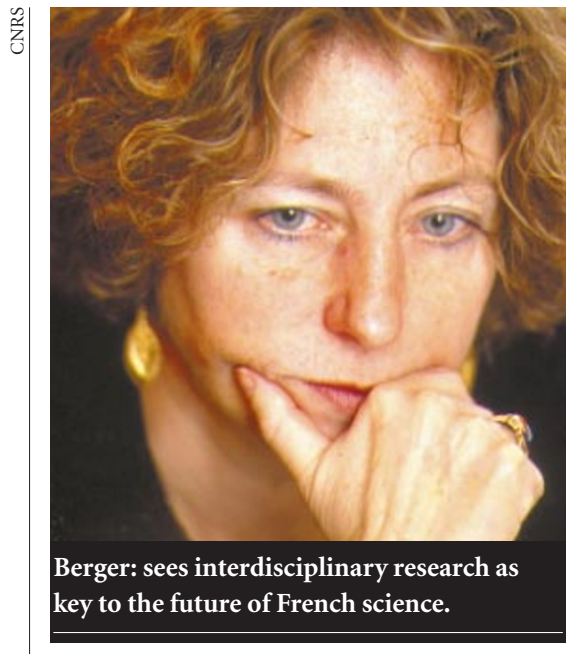

information technology over the next five years. Given that 74 of the new jobs will go to INSERM, and that many of the noncomputing posts at the CNRS will go to the life sciences, the harvest for other disciplines has been meagre. Jacques Fossey, secretary-general of the main researchers' trade union, the National Union of Scientific Researchers (SNCS), is among those critical of this imbalance.

But Geneviève Berger, the new director-general of the CNRS, says that she will not neglect physics and chemistry. Rather, in a bid to boost interdisciplinarity, she wants to see more researchers in these areas applying for jobs in life-science research.

Berger is also planning a bioinformatics programme to link the life sciences with the proposed information technology department. And she wants to introduce within six months a new 'matrix' model for research at the CNRS, with projects cutting across disciplinary boundaries.

Berger sees the wave of retirements as a golden opportunity to make the management of research more flexible. At present, over three-quarters of the CNRS budget goes on salaries, leaving little for equipment and supplies. She would like to see this cut to $60 \%$.

Berger does not intend to challenge researchers' status as civil servants. But she wants fewer full-time researchers and more temporary posts, to allow more foreign researchers to work at the CNRS. A system of three-year postdoctoral fellowships, renewable once, is also under consideration.

Having studied the budget figures, the SNCS claims that, despite the government's emphasis on job creation, it intends to increase spending on research infrastructure by cutting the wage bill. Describing this as "scandalous", the union is urging the National Assembly to amend the budget bill when it comes up for approval later in the autumn.

\title{
Disagreements derail US bill to double research funding...
}

Colin Macilwain, Washington

The hopes of US scientific societies that Congress would pass a bill to double research spending in each of the major nonmilitary research agencies collapsed last week, when the chairs of the relevant committees in the House and Senate failed to reach agreement on the bill's contents.

After four months of negotiations between the staff of James Sensenbrenner (Republican, Wisconsin), chair of the science committee in the House of Representatives, and Senator Bill Frist (Republican, Tennessee), Sensenbrenner refused to support Frist's proposal in the House - almost certainly ending its prospects of passage this year.

Sensenbrenner wants a bill supporting increased research funding in information technology, whereas Frist backs a much broader bill supporting all types of research.

In a detailed letter sent to Frist on 19 September, Sensenbrenner said that Frist's proposals "would provide little support for scientific research funding while undermining the science committee's ability to operate as an effective legislative entity".

If passed, Frist's bill would not guarantee a doubling of each agency's budget, but it would set an overall target for expenditure over several years. Sponsors hope this would influence the appropriations committees when they allocate the agencies' annual budgets.

Sensenbrenner is thought to oppose the bill mainly on the grounds of cost. But his letter argues that it would also reduce the prospects of Congress considering detailed legislation for science agencies — such as the
NASA reauthorization bill passed this year - and would further reduce his committee's influence on the appropriations process.

Two days after Sensenbrenner's letter, the Senate unanimously passed Frist's bill, the Federal Research Investment Act. But without Sensenbrenner's support, it has little chance of being considered by the House during this session.

In an angry reply to Sensenbrenner, Frist indicated that the science committee chairman had failed to live up to promises made in their negotiations. "You simply are holding the Federal Research Investment Act up to a different standard than you do your own committee bills," he wrote. He added that "anything less" than Sensenbrenner's support for the act "would be in direct contradiction to our previous negotiations".

Scientific societies, including the American Physical Society and the American Chemical Society, have been trying to build support for the measure for over three years (see Nature 394, 5; 1998). They believe the bill will ensure research agencies supporting the physical sciences - such as the Department of Energy - will not be left behind as Congress backs the rapid expansion of life sciences at the National Institutes of Health.

Some science lobbyists have said that the bill should be abandoned if it fails in the current session. But according to staff, Frist will pursue it in the new Congress next year. What ever happens in November's election, Sensenbrenner is not expected to chair the science committee. His departure will remove the largest single obstacle to the bill's passage.

\section{... as physical sciences plan lobbying body}

Scientific societies and research foundations plan to set up a lobbying body in Washington to boost public support for investment in the physical sciences, mathematics and engineering.

Impressed by the success of Research!America, a society that lobbies for the life sciences, various scientific bodies have provided around $\$ 100,000$ with which to prepare a business plan. The interim director of the body is to be Merrilea Mayo, a materials scientist from Pennsylvania State University.

The attempt to establish the as-yet-unnamed outfit has been spearheaded by Mary Good, a professor at the University of Arkansas and former undersecretary of technology at the commerce department in President Bill Clinton's administration. The physical sciences, says Good, "need a continuous presence" in

Washington. "We need to have the community speak with one voice, instead of 30 or 40 ."

Those involved in the effort say the precise role of the new body has yet to be defined, and that its success will depend on how much support it can attract

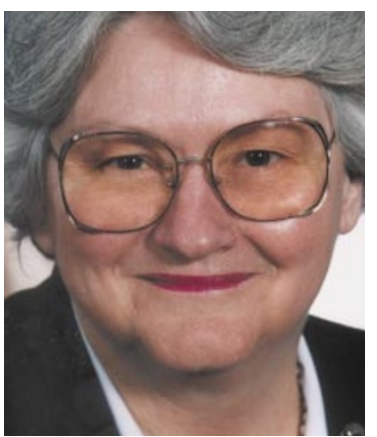

Good: believes the physical sciences need a single voice.

from sectors of industry that want the federal government to invest more in the physical sciences. C.M. 